Nadežda Langová
Teaching Assistant
Technical University in Zvolen
Slovakia
Paculty of Wood Sciences and Technology
Pavel Beňo
Associate professor
Faculty of Technology
Slovakia
Technical University in Zvolen
Jana Luptáková
Teaching Assistant
Technical University in Zvolen
The Institute of Foreign Languages
Slovakia
Cristiano Fragassa
Contract Professor
University of Bologna

\section{Stress Concentration around Circular and Elliptic Holes in Wood Laminates}

This paper examines the effects of material natural anisotropy of wood on stress concentration surrounding circular and elliptic holes. A thin anisotropic plate of wood was loaded with a constant pressure in one direction. The relationships between the stress components on the edge of the elliptic and circular holes were derived. For unloaded holes, normal stress values in small areas perpendicular to the edge of the hole were calculated. When calculating stress intensity, the relationships between the direction of applied pressure and the principal directions of elastic symmetry in spruce, ash, poplar, and oak wood were investigated.

Keywords: stress concentration factors, stress functions, circular hole, wood plate

\section{INTRODUCTION}

The presence of constructive or functional discontinuities (as holes, joints or so on), modifying the physical continuity in part geometry, can create high stress concentration zones [1].

Therefore, significant deformations can emerge, in the case either structural or non-structural parts, which can spread along the structure in the way of significantly decreasing strength, load-carrying capacity, and safety of the construction.

This change in properties can be particularly relevant when anisotropic materials are involved.

Between many others, wood is surely the most widely used material, affected by a natural anisotropy, or, in the presence of plenty of wood-based materials [2], by an artificial anisotropy.

Wood, in fact, is a strongly anisotropic and nonhomogeneous material by its nature. For use in engineered structures, the material needs to be graded in a process that estimates the mechanical properties in order to optimize its use [3].

In softwood, the main strength governing parameters are knots. These natural defects are causing weak spots and local fiber deviations that cause locally reduced strength properties, especially when loaded in tension or bending. Knots can be assigned to different subgroups, depending on the location of the center of the tree in timber [4]. These material features can have different shapes and can be visible on multiple surfaces. Fiber deviations around knots and natural defects are some aspects making wood a unique but complex material for structural applications.

As a consequence, the tensile strength properties (and not just those) of wood boards are strongly

Received: September 2019, Accepted: November 2019

Correspondence to: Dr. Nadežda Langová

Faculty of Wood Sciences and Technology,

T. G. Masaryka 24, 96001 Zvolen, Slovakia

E-mail: langova@tuzvo.sk

doi:10.5937/fmet2001102L

(C) Faculty of Mechanical Engineering, Belgrade. All rights reserved depending by these natural heterogeneities (knots, fibers, defects or so on) [5].

At the same time, as said, manufacturing or functional discontinuities (as holes, joints or so on) can affect the same properties [6].

Having more accurate information about all these geometrical features and their consequences for the strength may lead to more accurate strength predictions, a better machinability [7-10] and, thus, more economic use of the material.

Different studies are concentrated on the structural modelling of wood and predicting the strength reduction and failure, resulting from structural non-uniformities [11-14].

The question of the stress concentration around holes in wood materials is an important issue, especially from the viewpoint of production technologies by means of which these materials are manufactured, spatially or in the plane. During woodworking, in fact, cutting loads can act in several directions at the same time creating complex stress states.

A preliminary stress analysis in the case of an anisotropic wood plate with a circular hole loaded by a uniaxial tension is given by Savin[11] thanks to the use of an elastic ring as measure technique.

It can be said that the stress distribution around constructional holes is affected, in particular, by the material properties [12], but also by aspects as: the shape of a used joint, the distance of fasteners from the edges of structural members as well as by structural member thickness [13-17].

The use of new wood-based materials enables the presence of composites with high anisotropy in furniture and in structural constructions, joined by fasteners with various types and cross-sections.

The effect of the two parameters on the stress concentration around a hole is given in $[16,17]$.

This study proposes an experimental and numerical determination of the influence of holes of circular and elliptical shape on stress concentration. 
Thin anisotropic plates of 4 different kind of wood (spruce, ash, poplar, and oak) were loaded and the relationships stress components were derived. Stress intensities were evaluated using formula and considering the directions while a FEM analysis permitted to achieve a complete profile for the stress distribution.

\section{MATERIAL AND METHODS}

Concerning the given problems, the work analyses questions of the effect of material anisotropy around a circular hole in an infinite plate stressed by constant pressure in one direction in four tree species: spruce (Picea abies), ash (Fraxinus excelsior), poplar (Populus alba), and oak (Quercus cerris).

From the standpoint of designing a proper form of the structural member, in technical practices it is very important to solve cases of stress and strain in a body. When solving planar cases, stresses and deformations are dependent on two variables $\mathrm{x}, \mathrm{y}$. From a mathematical standpoint, the planar state of stress and planar state of deformation do not differ [9]. When solving this problem we start from the basic equations of the theory of elasticity of the plane state of stress in an anisotropic body (1) and (2):

$$
\begin{aligned}
& \frac{\partial \sigma_{x}}{\partial x}+\frac{\partial \tau_{x y}}{\partial y}+X=0 ; \frac{\partial \tau_{x y}}{\partial x}+\frac{\partial \sigma_{y}}{\partial y}+Y=0 \\
& \varepsilon_{x}=\frac{\partial u}{\partial x} ; \varepsilon_{y}=\frac{\partial v}{\partial y} ; \gamma_{x y}=\frac{\partial u}{\partial y}+\frac{\partial v}{\partial x}
\end{aligned}
$$

Relating to deformations we apply the equation of deformation continuity (3), i. e. compatibility equation, which is simultaneously a precondition of the integrability of the basic equations:

$$
\frac{\partial^{2} \varepsilon_{x}}{\partial y^{2}}+\frac{\partial^{2} \varepsilon_{y}}{\partial x^{2}}=\frac{\partial^{2} \gamma_{x y}}{\partial x \cdot \partial y}
$$

The boundary conditions take the form (4):

$$
\begin{aligned}
& X_{n}=\sigma_{x} \cdot \cos (n, x)+\tau_{x y} \cdot \cos (n, y) \\
& Y_{n}=\tau_{x y} \cdot \cos (n, x)+\sigma_{y} \cdot \cos (n, y)
\end{aligned}
$$

Solving planar problems of the theory of elasticity in anisotropic bodies, it is advisable to introduce the Airy stress function by relations (5):

$$
\sigma_{x}=\frac{\partial^{2} F}{\partial y^{2}}+U, \sigma_{y}=\frac{\partial^{2} F}{\partial x^{2}}+U, \tau_{x y}=-\frac{\partial^{2} F}{\partial x . \partial y}
$$

where: $\mathrm{U}$ - body force potential.

After substitution into physical equations and subsequently into the equation of deformation continuity compatibility equation, we obtain the equation (6):

$$
\begin{aligned}
& a_{22} \cdot \frac{\partial^{4} F}{\partial x^{4}}-2 \cdot a_{26} \cdot \frac{\partial^{4} F}{\partial x^{3} \cdot \partial y}+\left(2 \cdot a_{12}+a_{66}\right) \cdot \frac{\partial^{4} F}{\partial x^{2} \cdot \partial y^{2}}- \\
& -2 \cdot a_{16} \cdot \frac{\partial^{4} F}{\partial x \cdot \partial y^{3}}+a_{11} \cdot \frac{\partial^{4} F}{\partial y^{4}}=-\left(a_{12}+a_{22}\right) \cdot \frac{\partial^{2} U}{\partial x^{2}}+ \\
& +\left(a_{16}+a_{26}\right) \cdot \frac{\partial^{2} U}{\partial x \cdot \partial y}-\left(a_{11}+a_{12}\right) \cdot \frac{\partial^{2} U}{\partial y^{2}}
\end{aligned}
$$

This partial differential equation is a basic equation in the theory of elasticity of anisotropic bodies [18-22]. When body forces do not act on a body, or when they are constant, instead of (6) we obtain the homogeneous partial fourth-order differential equation:

$$
\begin{aligned}
& a_{22} \cdot \frac{\partial^{4} F}{\partial x^{4}}-2 \cdot a_{26} \cdot \frac{\partial^{4} F}{\partial x^{3} \cdot \partial y}+\left(2 \cdot a_{12}+a_{66}\right) \cdot \\
& \frac{\partial^{4} F}{\partial x^{2} \cdot \partial y^{2}}-2 \cdot a_{16} \cdot \frac{\partial^{4} F}{\partial x \cdot \partial y^{3}}+a_{11} \cdot \frac{\partial^{4} F}{\partial y^{4}}=0
\end{aligned}
$$

In the case of the orthotropic plate and on the assumption that axes of the coordinate system $\mathrm{x}, \mathrm{y}$ are corresponding with the principal directions of elastic symmetry, equations (6) and (7) are reduced to the equation (8):

$$
a_{22} \cdot \frac{\partial^{4} F}{\partial x^{4}}+\left(2 \cdot a_{12}+a_{66}\right) \cdot \frac{\partial^{4} F}{\partial x^{2} \cdot \partial y^{2}}+a_{11} \cdot \frac{\partial^{4} F}{\partial y^{4}}=0
$$

Introducing the stress function $\mathrm{F}$ is also shown in the boundary conditions which can be written in the form (9a, 9b):

$$
\begin{aligned}
& \frac{\partial^{2} F}{\partial y^{2}} \cdot \cos (n, x)-\frac{\partial^{2} F}{\partial x \cdot \partial y} \cdot \cos (n, y)= \\
& =X_{n}-U(x, y) \cdot \cos (n, x) \\
& -\frac{\partial^{2} F}{\partial x \cdot \partial y} \cdot \cos (n, x)+\frac{\partial^{2} F}{\partial y x^{2}} \cdot \cos (n, y)= \\
& =Y_{n}-U(x, y) \cos (n, y)
\end{aligned}
$$

An advantage of introducing the stress function $\mathrm{F}$ lies in the fact that instead of five basic equations (1) and (2) by which we can determine three stress components $\sigma_{\mathrm{x}}, \sigma_{\mathrm{y}}, \tau_{\mathrm{xy}}$ and two deformation components $\mathrm{u}$, $\mathrm{v}$ we obtain only one equation (7). The planar problem is solved by finding the Airy function of the state of stress $F$ which is to satisfy equation (7) meeting the boundary conditions. According to S. G. Lechnickii [18], we express the stress function $F$ by two analytical functions $\varphi\left(z_{1}\right)$ and $\psi\left(z_{2}\right)$, which enables us to express the stress components $\sigma_{\mathrm{x}}, \sigma_{\mathrm{y}}, \tau_{\mathrm{xy}}$ in the forms (10):

$$
\begin{aligned}
& \sigma_{x}=2 \cdot \operatorname{Re}\left[\mu_{1}^{2} \cdot \varphi^{\prime}\left(z_{1}\right)+\mu_{2}^{2} \cdot \psi^{\prime}\left(z_{2}\right)\right] \\
& \sigma_{y}=2 \cdot \operatorname{Re}\left[\varphi^{\prime}\left(z_{1}\right)+\psi^{\prime}\left(z_{2}\right)\right] \\
& \tau_{x y}=-2 \cdot \operatorname{Re}\left[\mu_{1} \cdot \varphi^{\prime}\left(z_{1}\right)+\mu_{2} \cdot \psi^{\prime}\left(z_{2}\right)\right]
\end{aligned}
$$

where: Re - real part of the expressions in square brackets, while: $\varphi^{\prime}\left(z_{1}\right)=\frac{d \varphi}{d z_{1}} ; \psi^{\prime}\left(z_{2}\right)=\frac{d}{d z_{2}}, \mu_{1}, \mu_{2}-$ complex parameters.

By substituting for $\sigma_{x}, \sigma_{y}, \tau_{x y}$ into the physical equations and integrating, we will obtain displacement components $\mathrm{u}, \mathrm{v}(11)$ :

$$
\begin{aligned}
& u(x, y)=2 \cdot \operatorname{Re}\left[p_{1} \cdot \varphi\left(z_{1}\right)+p_{2} \cdot \psi\left(z_{2}\right)\right]-\gamma_{0} y+\alpha_{0} \\
& v(x, y)=2 \cdot \operatorname{Re}\left[p_{1} \cdot \varphi\left(z_{1}\right)+p_{2} \cdot \psi\left(z_{2}\right)\right]-\gamma_{0} y+\beta_{0}
\end{aligned}
$$


where:

$$
\begin{aligned}
& p_{1}=a_{11} \cdot \mu_{1}^{2}+a_{12}-a_{16} \cdot \mu_{1} \\
& p_{2}=a_{11} \cdot \mu_{2}^{2}+a_{12}-a_{16} \cdot \mu_{1} \\
& q_{1}=a_{12} \cdot \mu_{1}+\frac{a_{22}}{\mu_{1}}-a_{16} \\
& q_{2}=a_{12} \cdot \mu_{2}+\frac{a_{22}}{\mu_{1}}-a_{16}
\end{aligned}
$$

Constants $\alpha_{0}, \beta_{0}, \gamma_{0}$ characterize the displacement of a body as a whole and they are determined from the conditions of body support. From the boundary conditions that have to correspond with functions $\varphi\left(z_{1}\right)$ and $\psi\left(\mathrm{z}_{2}\right)$, for $\mathrm{U}=0$, we obtain:

$$
\begin{aligned}
& \varphi\left(z_{1}\right)+\overline{\varphi\left(z_{1}\right)}+\psi\left(z_{2}\right)+\overline{\psi\left(z_{2}\right)}= \\
& =-\int_{0}^{s} Y_{n} d s+c_{1}=f_{1} \\
& \mu_{1} \varphi\left(z_{1}\right)+\overline{\mu_{1} \varphi\left(z_{1}\right)}+\mu_{2} \psi\left(z_{2}\right)+\overline{\mu_{2} \psi\left(z_{2}\right)}= \\
& ==\int_{0}^{s} X_{n} d s+d_{i}=f_{2}
\end{aligned}
$$

By the above-mentioned S. G. Lechnicky's method [18], we have expressed stress components by means of two analytical functions $\varphi\left(z_{1}\right)$ and $\psi\left(z_{2}\right)$ by relations (10). The displacement components have also been expressed by functions $\varphi\left(z_{1}\right)$ and $\psi\left(z_{2}\right)$ by relations (11). This way, solving the basic problems of elasticity is carried out as searching the functions $\varphi\left(z_{1}\right)$ and $\psi\left(z_{2}\right)$ from the boundary conditions. For the case of stress component $\sigma$ on a circular hole edge and for the case of the plate loaded by pressure was derived the relation (12):

$\sigma_{\vartheta}=-p[\cos \alpha \cdot \sin \vartheta+\sin \alpha \cdot \cos \vartheta]^{2}+$

$$
+\operatorname{Re}\left\{\begin{array}{l}
\frac{p e^{-i \vartheta}\left(\mu_{1} \cdot \sin \vartheta+\cos \vartheta\right)^{2}}{2 i\left(\mu_{1}-\mu_{2}\right) \cdot\left(\sin \vartheta-\mu_{1} \cdot \cos \vartheta\right)} . \\
\cdot\left[\left(2 \mu_{2} \cdot \sin ^{2} \alpha+\sin 2 \alpha\right)-i\left(\mu_{2} \cdot \sin 2 \alpha+2 \cos ^{2} \alpha\right)\right]
\end{array}\right\}-
$$

$$
-\operatorname{Re}\left\{\begin{array}{l}
\frac{p e^{-i \vartheta}\left(\mu_{2} \cdot \sin \vartheta+\cos \vartheta\right)^{2}}{2 i\left(\mu_{1}-\mu_{2}\right) \cdot\left(\sin \vartheta-\mu_{2} \cdot \cos \vartheta\right)} \cdot\left[\begin{array}{l}
\left(2 \mu_{1} \cdot \sin ^{2} \alpha+\sin 2 \alpha\right)- \\
-i\left(\mu_{1} \cdot \sin 2 \alpha+2 \cos ^{2} \alpha\right)
\end{array}\right] \\
\}
\end{array}\right\}
$$

\subsection{Preconditions of the solution}

a) The hole dimensions are considered to be relatively small by comparison with dimensions of the plate. The hole does not lie in the neighbourhood of the edge of the plate. The problem is then carried out by solving an infinite plane weakened by a hole.

b) General Hooke's law and precondition for small deformations are applied for the plate material.

c) The plate has three planes of elastic symmetry - it is orthogonally anisotropic (orthotropic).

d) Axes of the coordinate system $x, y$ are parallel with the principal directions of elastic symmetry (Fig. 1a). e) The plate is loaded by constant pressure $p$ in a sufficiently big distance from the hole. The load makes an angle $\alpha$ with the $\mathrm{x}$-axis (Fig. 1b)

f) The edge of the hole is unloaded.

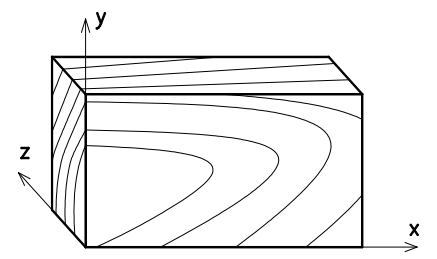

a)
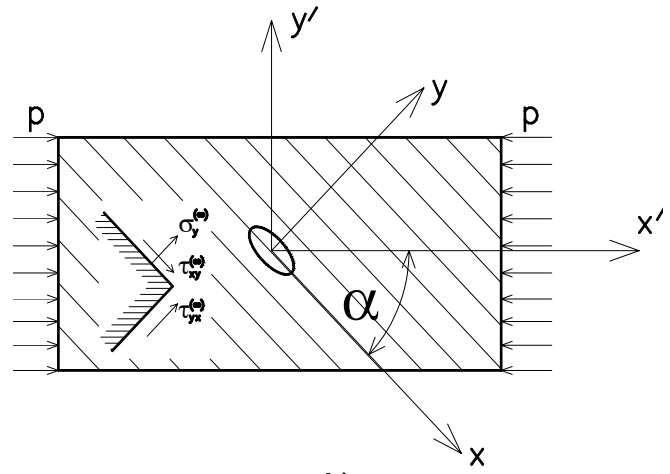

b)

Figure1. a) Coordinate system of the orthotropic plate, b) Infinite plane weakened by an elliptic hole

\subsection{Calculation of stress on the edge of a circular hole}

We start from the results of measuring the coefficients of elongation elasticity $E_{x}, E_{y}$, shear moduli $G_{x y}$ and Poisson numbers $\mu_{\mathrm{xy}}, \mu_{\mathrm{yx}}$ [18]. Results for $\mathrm{x}, \mathrm{y}$ plane are given in Table 1.

The deformation coefficients $a_{11}, a_{12}, a_{22}, a_{66}$ are calculated from the transforming formulas:

$$
\begin{aligned}
& a_{11}=\frac{\cos ^{2} \alpha}{E_{x}}+\left(\frac{1}{G_{x y}}-\frac{2 \vartheta_{x y}}{E_{x}}\right) \cdot \sin ^{2} \alpha \cdot \cos ^{2} \alpha+\frac{\sin ^{4} \alpha}{E_{y}} \\
& a_{22}=\frac{\sin ^{2} \alpha}{E_{x}}+\left(\frac{1}{G_{x y}}-\frac{2 \vartheta_{x y}}{E_{x}}\right) \cdot \sin ^{2} \alpha \cdot \cos ^{2} \alpha+\frac{\cos ^{4} \alpha}{E_{y}} \\
& a_{12}=\left(\frac{1+\vartheta_{x y}}{E_{x}}+\frac{1+\vartheta_{x y}}{E_{y}}-\frac{1}{G_{x y}}\right) \cdot \sin ^{2} \alpha \cdot \cos ^{2} \alpha-\frac{\vartheta_{x y}}{E_{x}} \\
& a_{66}=\frac{1}{G_{x y}}+4\left(\frac{1+\vartheta_{x y}}{E_{x}}+\frac{1+\vartheta_{x y}}{E_{y}}-\frac{1}{G_{x y}}\right) \cdot \sin ^{2} \alpha \cdot \cos ^{2} \alpha
\end{aligned}
$$

\section{RESULTS AND DISCUSSION}

Deformation coefficients are given in Tables 2 and 3 . The stress (denoted $\sigma$ ) at the edges of an unloaded circular hole in the infinite plate, stressed by constant pressure, was calculated to deduce the following:

- the point on the edge at which the angle of extreme stress values was created;

- the angle $\alpha$ at which the extreme values of stress $\sigma$ were created. The angle $\alpha$ is created by the principal directions of symmetry, as well as the loading direction. 
Table 1. Elasticity coefficients and Poisson's ratios in $x, y$ plane [18].

\begin{tabular}{|l|c|c|c|c|}
\hline \multirow{2}{*}{$\begin{array}{c}\text { Elastic } \\
\text { properties }\end{array}$} & \multicolumn{4}{|c|}{ Tree species } \\
\cline { 2 - 5 } & Picea abies & Fraxinus excelsior & Populus alba & Quercus cerris \\
\hline $\mathrm{E}_{\mathrm{x}}\left(10^{5} \mathrm{~Pa}\right)$ & 136.502 & 157.985 & 139.380 & 117.785 \\
\hline $\mathrm{E}_{\mathrm{y}}\left(10^{5} \mathrm{~Pa}\right)$ & 2.895 & 12.687 & 3.496 & 10.289 \\
\hline $\mathrm{G}_{\mathrm{xy}}\left(10^{5} \mathrm{~Pa}\right)$ & 4.740 & 10.820 & 3.860 & 6.500 \\
\hline$\mu_{\mathrm{xy}}(-)$ & 0.557 & 0.566 & 0.590 & 0.452 \\
\hline$\mu_{\mathrm{yx}}(-)$ & 0.012 & 0.045 & 0.015 & 0.039 \\
\hline
\end{tabular}

Table 2. Deformation coefficients. The direction of $x$-axis is corresponding with the direction of the greater elasticity coefficient.

\begin{tabular}{|c|c|c|c|c|c|c|}
\hline & & & Picea abies & Fraxinus excelsior & Populus alba & Quercus cerris \\
\hline$a_{11}$ & $1 / \mathrm{E}_{\mathrm{y}}$ & \multirow{4}{*}{$1 / 10^{5} \mathrm{~Pa}$} & $1 / 136.502$ & $1 / 157.985$ & $1 / 139.380$ & $1 / 117.785$ \\
\hline$a_{12}$ & $\mu_{\mathrm{yx}} / \mathrm{E}_{\mathrm{x}}$ & & $-(0.557 / 136.502)$ & $-(0.566 / 157.985)$ & $-(0.590 / 139.380)$ & $-(0.452 / 117.785)$ \\
\hline$a_{22}$ & $1 / E_{x}$ & & $1 / 2.895$ & $1 / 12.687$ & $1 / 3.496$ & $1 / 10.289$ \\
\hline$a_{66}$ & $1 / \mathrm{G}_{\mathrm{xy}}$ & & $1 / 4.740$ & $1 / 10.820$ & $1 / 3.860$ & $1 / 6.500$ \\
\hline
\end{tabular}

Table 3. Deformation coefficients. The direction of $x$-axis is corresponding with the direction of the lower elasticity coefficient.

\begin{tabular}{|c|c|c|c|c|c|c|}
\hline \multicolumn{2}{|c|}{} & Picea abies & Fraxinus excelsior & Populus alba & Quercus cerris \\
\hline $\mathrm{a}_{11}$ & $1 / \mathrm{E}_{\mathrm{y}}$ & \multirow{4}{*}{$1 / 10^{5} \mathrm{~Pa}$} & $1 / 2.895$ & $1 / 12.687$ & $1 / 3.496$ & $1 / 10.289$ \\
\cline { 4 - 6 } $\mathrm{a}_{12}$ & $\mu_{\mathrm{yx}} / \mathrm{E}_{\mathrm{x}}$ & $-(0.012 / 2.895)$ & $-(0.045 / 12.687)$ & $-(0.015 / 3.496)$ & $-(0.039 / 10.289)$ \\
\cline { 4 - 6 } $\mathrm{a}_{22}$ & $1 / \mathrm{E}_{\mathrm{x}}$ & $1 / 136.502$ & $1 / 157.985$ & $1 / 139.380$ & $1 / 117.785$ \\
\cline { 4 - 6 } $\mathrm{a}_{66}$ & $1 / \mathrm{G}_{\mathrm{xy}}$ & $1 / 4.740$ & $1 / 10.820$ & $1 / 3.860$ & $1 / 6.500$ \\
\cline { 4 - 6 } & & &
\end{tabular}

By solving basic equation (14) which is characteristic by equation (15), we obtain complex parameters. Results of the calculations are given Table 4.

$$
\begin{aligned}
& a_{11} \cdot \frac{\partial^{4} F}{\partial y^{4}}+\left(2 a_{12}+a_{66}\right) \cdot \frac{\partial^{4} F}{\partial x^{2} \cdot \partial y^{2}}+a_{22} \cdot \frac{\partial^{4} F}{\partial x^{4}} \\
& a_{11} \cdot \mu^{4}+\left(2 a_{12}+a_{66}\right) \cdot \mu^{2}+a_{22}=0
\end{aligned}
$$

We carry out the transformation of the complex parameters for different angles $\alpha$ and according to relations (16) we calculate $\sigma / \mathrm{p}$.

$$
\mu_{1}^{\prime}=\frac{\mu_{1} \cdot \cos \alpha-\sin \alpha}{\cos \alpha+\mu_{1} \cdot \sin \alpha} ; \mu_{2}^{\prime}=\frac{\mu_{2} \cdot \cos \alpha-\sin \alpha}{\cos \alpha+\mu_{21} \cdot \sin \alpha}
$$

Results of the calculations for the observed materials are given in Tables 5 and 6 , graphic representation $\sigma / \mathrm{p}$ for two mentioned basic cases is in Graphs 2a and 2c.

In all examined cases, the edge of the hole breaks into four areas of the stress concentration distributed symmetrically towards the centre of the hole. The signs + and - are used to mark the areas in which tensile or

\begin{tabular}{|c|c|c|}
\hline \multirow[t]{2}{*}{ Tree species } & \multicolumn{2}{|c|}{$\begin{array}{l}\text { Complex parameters. Direction of } x \text {-axis is corresponding with the } \\
\text { direction of the greater elasticity coefficient. }\end{array}$} \\
\hline & $\mu_{1}$ & $\mu_{2}$ \\
\hline Picea abies & $5.0945 \mathrm{i}$ & $1.3517 \mathrm{i}$ \\
\hline Fraxinus excelsior & $3.5410 \mathrm{i}$ & $0.9980 \mathrm{i}$ \\
\hline Populus alba & $5.8410 \mathrm{i}$ & $1.0870 \mathrm{i}$ \\
\hline Quercus cerris & $4.0880 \mathrm{i}$ & $0.8320 \mathrm{i}$ \\
\hline \multirow[t]{2}{*}{ Tree species } & \multicolumn{2}{|c|}{$\begin{array}{l}\text { Complex parameters. Direction of } x \text {-axis is corresponding with the } \\
\text { direction of the lower elasticity coefficient. }\end{array}$} \\
\hline & $\mu_{1}$ & $\mu_{2}$ \\
\hline Picea abies & $0.1963 \mathrm{i}$ & $0.7398 \mathrm{i}$ \\
\hline Fraxinus excelsior & $0.2820 \mathrm{i}$ & $1.0020 \mathrm{i}$ \\
\hline Populus alba & $0.11710 \mathrm{i}$ & $0.9200 \mathrm{i}$ \\
\hline Quercus cerris & $0.2440 \mathrm{i}$ & $1.2030 \mathrm{i}$ \\
\hline
\end{tabular}
pressure stresses $\sigma$ are formed.

Table 4. Calculated complex parameters.

Table 5. Course of $/ p$ along the circumference of the circular hole, angle $\alpha=0^{\circ}$

\begin{tabular}{|c|c|c|c|c|c|c|c|c|c|}
\hline \multirow{2}{*}{$*$} & \multirow{2}{*}{$\begin{array}{l}\text { Isotropic } \\
\text { material }\end{array}$} & \multicolumn{4}{|c|}{$\begin{array}{c}\text { Load acting in the direction of the greater } \\
\text { elasticity coefficient }\end{array}$} & \multicolumn{3}{c|}{$\begin{array}{c}\text { Load acting in the direction of the lower elasticity } \\
\text { coefficient }\end{array}$} \\
\cline { 3 - 11 } & Picea abies & $\begin{array}{c}\text { Fraxinus } \\
\text { excelsior }\end{array}$ & $\begin{array}{c}\text { Populus } \\
\text { alba }\end{array}$ & $\begin{array}{c}\text { Quercus } \\
\text { cerris }\end{array}$ & Picea abies & $\begin{array}{c}\text { Fraxinus } \\
\text { excelsior }\end{array}$ & $\begin{array}{c}\text { Populus } \\
\text { alba }\end{array}$ & $\begin{array}{c}\text { Quercus } \\
\text { cerris }\end{array}$ \\
\hline 0 & +1.0000 & +0.1452 & +0.2830 & +0.1575 & +0.2940 & +6.8859 & +3.5390 & +69.356 & +3.4067 \\
\hline 10 & +0.8794 & +0.1421 & +0.2686 & +0.1519 & +0.2739 & +2.1771 & +1.9052 & +1.7978 & +1.6709 \\
\hline 20 & +0.5321 & +0.1307 & +0.2221 & +0.1333 & +0.2133 & -1.0839 & -0.0940 & -0.8562 & -0.1121 \\
\hline 30 & 0.0000 & +0.1311 & +0.1311 & +0.0947 & +0.1089 & -2.0363 & -1.0224 & -1.6688 & -0.9952 \\
\hline 40 & -0.6527 & +0.0415 & -0.0278 & +0.0230 & -0.0537 & -2.2266 & -1.6876 & -1.9707 & -1.4827 \\
\hline 50 & -1.3473 & -0.1004 & -0.3115 & -1.285 & -0.3164 & -2.1962 & -1.9711 & -2.0717 & -1.8143 \\
\hline
\end{tabular}




\begin{tabular}{|c|l|l|l|l|l|l|l|l|l|}
\hline 60 & -2.0000 & -0.4423 & -0.8431 & -0.4493 & -0.7892 & -2.1016 & -2.1311 & -2.0995 & -2.0718 \\
\hline 70 & -2.5321 & -1.3413 & -1.9027 & -1.2572 & -1.7654 & -2.0137 & -2.2220 & -2.0999 & -2.2746 \\
\hline 80 & -2.8794 & -3.9050 & -3.9065 & -3.7309 & -3.7947 & -1.9559 & -2.2693 & -2.0939 & -2.4316 \\
\hline 90 & -3.0000 & -7.4462 & -5.5387 & -7.9280 & -5.9199 & -1.9361 & -2.2840 & -2.0910 & -2.4470 \\
\hline 100 & -2.8794 & -3.9050 & -3.9065 & -3.7309 & -3.7947 & -1.9559 & -2.2693 & -2.0939 & -2.4316 \\
\hline 110 & -2.5321 & -1.3413 & -1.9027 & -1.2572 & -1.7654 & -2.0137 & -2.2220 & -2.0999 & -2.2746 \\
\hline 120 & -2.0000 & -0.4423 & -0.8431 & -0.4493 & -0.7892 & -2.1016 & -2.1311 & -2.0995 & -2.0718 \\
\hline 130 & -1.3473 & -0.1004 & -0.3115 & -0.1285 & -0.3164 & -2.1962 & -1.9711 & -2.0717 & -1.8148 \\
\hline 140 & -0.6527 & +0.0415 & -0.0278 & +0.0230 & -0.0537 & -2.2266 & -1.6876 & -1.9707 & -1.4827 \\
\hline 150 & 0.0000 & +0.1034 & +0.1311 & +0.0947 & +0.1089 & -2.0363 & -1.0224 & -1.6688 & -0.9952 \\
\hline 160 & +0.5321 & +0.1307 & +0.2221 & +0.1333 & +0.2133 & -1.0839 & -0.0940 & -0.8562 & -0.1121 \\
\hline 170 & +0.8794 & +0.1421 & +0.2686 & +0.1519 & +0.2739 & +2.1771 & +1.9052 & +1.7978 & +1.6709 \\
\hline 180 & +1.000 & +0.1452 & +0.2830 & +0.1575 & +0.2940 & +6.8859 & +3.5390 & +6.3565 & +3.4067 \\
\hline
\end{tabular}

To determine the absolute value of the highest stress $\sigma$ in orthotropic materials, calculations are made for two basic cases: the plate is loaded by constant pressure in the direction of either the greater or the lower elasticity coefficient. Both cases are based on the assumption that the axes of the coordinate system $\mathrm{x}, \mathrm{y}$ (Fig. 2 ) are parallel to the principal axes of elastic symmetry. This characteristic has been described previously [20]; this study also specified for an infinite orthotropic plate with a circular hole stressed by pure shear.

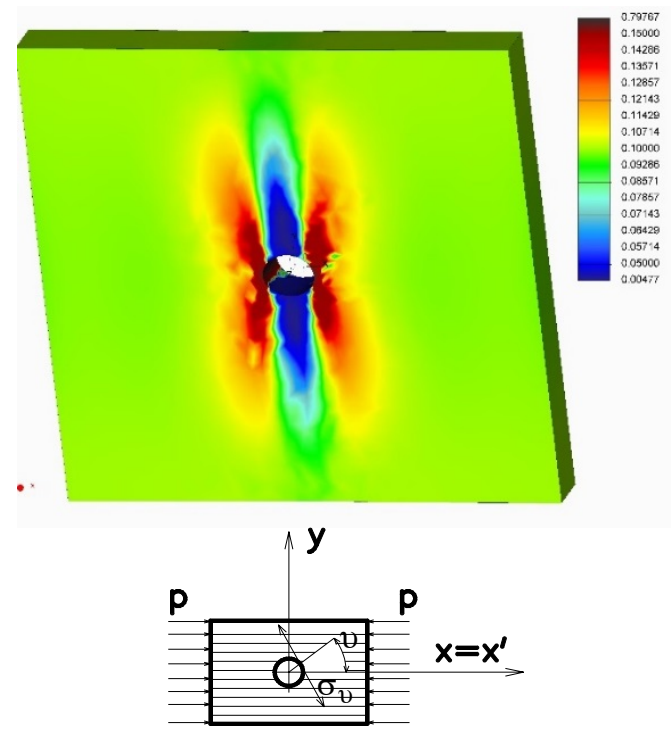

a)
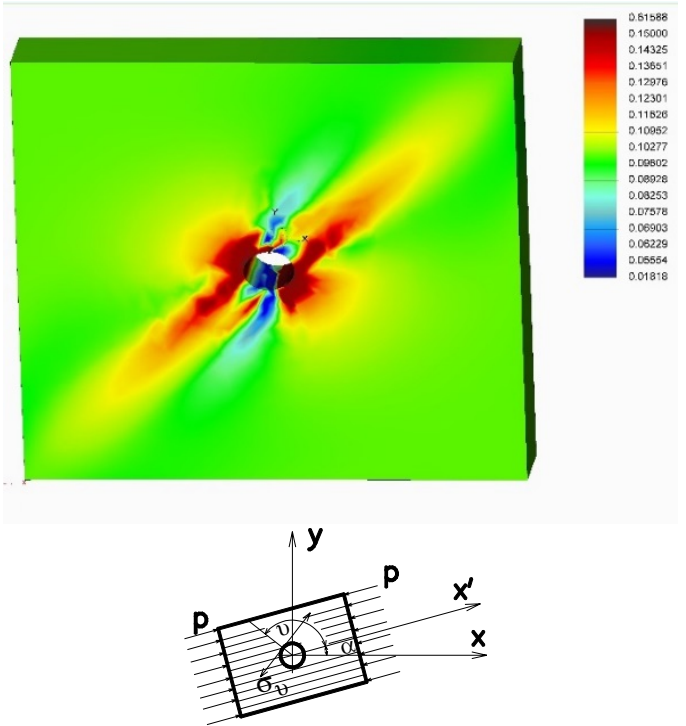

b)
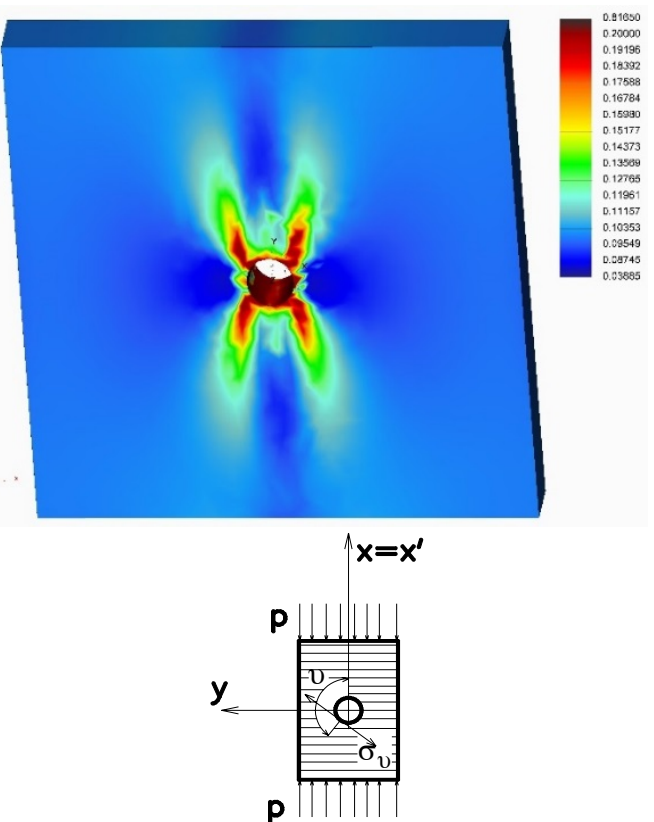

c)

Figure 2. Course of $/ p$ along the circumference of the circular hole for spruce (Picea abies) for angle $\quad \alpha=0^{\circ}$ (a and c) andangle $\alpha=15^{\circ}(\mathrm{b})$

Based on of the calculations and simulations mentioned in this article we can conclude that stress distribution around a defined shape of the hole depends on the material properties and, also, the angle of inclination of wood fibres [19]. This conclusion is confirmed in Bodnar's work [1] as well, which examined the various shapes of holes, (circular, elliptical, normal square and rotated square hole) and the most degree of stress concentration was watched at rotated square hole. Of the material point of view of wood, the most disadvantageous is Picea abies in generally.

The stress concentration at the edge of a cut-out is of practical importance in designing of the furniture construction and building structures. These stresses determine the distance of the fasteners in joints of wooden elements. From the shape of the fasteners depends also the shape of the hole in joined elements. The study [17] presented an analytical solution for stresses in composite plates with special shaped cutouts. Leknitsjki's solution for circular and elliptical cutout is extended to special cut-out shape using complex variable mapping. This complex variable function can be used in modelling and evaluation of stress distribution in perforated composite and isotropic plates. 
The stress concentration factor of perforated plates can be significantly change by using proper material properties and cut-out parameters.

\section{CONCLUSIONS}

This work includes analytical and numerical studies on the stress distribution around a circular hole in the orthotropic plate, using four tree species that are exploited in furniture or structural constructions (spruce, ash, poplar, and oak).

From all possible directions, extreme stress values $\sigma$ appear if the load direction corresponds with the principal direction of elastic symmetry (angle $\alpha=0^{\circ}$ ). Meanwhile, with an isotropic plate stressed by constant pressure " $p$ " in the direction of the $x$-axis, the highest stress $\sigma_{v}$ in the absolute value appears at the angle $=$ $\pm \pi / 2$.

According to the aforementioned facts, in practical calculations, the cases of construction part need to be differentiated between loading parallel with the fibers and perpendicular to the fibers. The stress concentration factor achieves maximal value when fibers are orientated parallel to the plate axis.

The calculations of $\sigma / p$ and their graphic representation show that the graphic course of stress areas is repeated with the change of angle $\alpha \in\langle\pi / 4, \pi / 2\rangle$. Thus, the stress distribution at the angle $\alpha=75^{\circ}$ is obtained from the graph of the stress distribution at the angle $\alpha=15^{\circ}$ by its reversing around the $\mathrm{x}$-axis, by an angle of $180^{\circ}$.

\section{ACKNOWLEDGMENTS}

This work was supported by the grant agency VEGA under the project No. 1/0556/19 Lightweight wood veneers based materials and their application in products.

\section{REFERENCES}

[1] Bodnár, F.: Solution of stresses around holes in wooden plate under inplane loading, In.: Kúdela. J., Kuriatko, S., Lagaňa, R.: Wood structure and properties '06. Zvolen: Arbora Publishers, 2006. 522s. ISBN 80-968869-4-3.

[2] Foley, C.: A three-dimensional paradigm of fiber orientation in timber. Wood science and technology, Vol. 35, No. 5, pp. 453-465, ISSN 0043-7719, 2001.

[3] Cramer, S.M. and Goodman, J.R.: A basis for strength prediction of lumber, Wood Fiber Sci, Vol. 18, No. 3, pp. 446-459, 1986.

[4] Guindos, P.: A three-dimensional wood material model to simulate the behavior of wood with any type of knot at the macro-scale. Wood science and technology, Vol. 47, No. 3, pp. 585-599, ISSN 0043-7719, 2013.

[5] Hu, M.: Growth layer and fibre orientation around knots in Norway spruce: a laboratory investigation. Wood science and technology, Vol. 52, No. 1, pp. 7-27, ISSN 0043-7719, 2018.

[6] Langová N.: Analysis of stress and strain around joints with pin-type connections (Analyza stavu napätosti a deformácii okolo spojov kolikového typu). PhD thesis, Faculty of Wood Sciences and Technology, Technical University in Zvolen, Zvolen, 2001.

[7] Zigulic, R., Fragassa, C. Skoblar, A.: Influence of the longitudinal displacement on nonlinear principal parametric resonance of the woodworking bandsaw. Tehnicki Vjesnik. Vol. 24, No. 1, pp. 253263, DOI:10.17559/TV-20160209175450, 2017

[8] Fragassa, C., Lucisano, G., Marinkovic, D. Campana, G.: A Practical Guideline for the Design and Use of Tools in Woodworking. FME Transactions, Vol. 47, No. 2, pp. 487-495, doi: 10.5937/fmet1903487F, 2019.

[9] Fragassa, C.: Material selection in machine design: the change of cast iron for improving the highquality in woodworking. Proceedings Institution of Mechanical Engineers, Part C: Journal of Mechanical Engineering Science, Vol. 231, No. 1, pp. 1830. DOI: 10.1177/0954406216639996, 2016.

[10] Lucisano, G., Stefanovic, M. Fragassa, C. Advanced Design Solutions for High-Precision Woodworking Machines. International Journal of Quality Research, Vol. 10, No. 1, pp. 143-158, 2016.

[11] Savin, G. N.: Raspredelenije naprjaženij okolo otverstij (Stress distribution near holes), Naukova dumka, Kijev, 1968.

[12]Brilla, J.: Anizotropické steny (Anisotropic plates), Vydavatel'stvo Slovenskej akadémie vied, Bratislava, 1958.

[13] Yavari, V., Rajabi, I., Daneshvar, F. and Kadivar, M.H.: On the stress distribution around the hole in mechanically fastened joints. Mechanics Research Communications Vol. 36, No. 3, pp. 275-418, ISSN: 0093-6413, 2008.

[14] Engels, H. and Becker, W.: Optimization of patch reinforcements around circular holes in isotropic and anisotropic plates, Zeitschrift fur angewandte mathematik und mechanic, Vol. 81, No. 3, pp: S663-S664, ISSN: 0044-2267, 2001.

[15] Khechai, A.: Strength degradation and stress analysis of composite plates with circular, square and rectangular notches using digital image correlation. Composite structures, Vol. 185, pp. 699-715, ISSN 0263-8223, 2018.

[16] Nageswara Raoa, D.K., Ramesh Babub, M., Narender Reddyc, K. R. and Sunild, D.: Stress around square and rectangular cutouts in symmetric laminates, Composite Structures, Vol. 92, No. 12, pp. 2845-2859. DOI:10.1016/j.compstruct.2010.04.010, 2010.

[17] Rezaeepazhand, J. and Jafari, M.: Stress analysis of perforated composite plates, Composite Structures, Vol. 71, No. 3-4, pp. 463-468. DOI:10.1016/j.compstruct.2005.09.017, 2005

[18] Lechnickij, S. G.: Anizotropnyje plastinki, Gosudarstvennoje izdavatelsvo techn.-teoret. literatury, Moskva, 1957.

[19]Babiak, M. and Dubovský, J.: Problémy z mechanických vlastností dreva. (Problems of 
mechanical wood properties). Guide book, Technical University in Zvolen, 2001.

[20]Jawaid, M. and Thariq, M. (Editors): Handbook Sustainable Composites for Aerospace Applications, Woodhead Publishing - Elsevier, Cambridge, 2018.

[21]Zweben C.H., Beaumont P.W.R. (Editors): Comprehensive Composite Materials II, 2nd Edition, Elsevier Ltd., Amsterdam, 2018.

[22]Beaumont P.W.R., Soutis C., Hodzic A. (Editors): Structural integrity and durability of advanced composites: Innovative modelling methods and intelligent design, Woodhead Publishing - Elsevier, Cambridge, 2015.

\section{КОНЦЕНТРАЦИЈА НАПОНА ОКО КРУЖНИХ И ЕЛИПТИЧНИХ РУПА У ДРВЕНИМ ЛАМИНАТИМА}

\section{Н. Лангова, П. Бено, Ј. Луптакова, К. Фрагаса}

Овај рад испитује ефекте природне анизотропије дрвета на концентрацију напрезања у окружним и елиптичним отворима. Танка анизотропна плоча од дрвета била је оптерес́ена сталним притиском у једном правцу. Изведени су односи између компонената напрезања на ивици елиптичне и кружне рупе. За неотворене рупе израчунате су нормалне вредности напона у малим деловим на ивици рупе. При израчунавању интензитета напрезања испитиване су везе између смера примењеног притиска и главних смерова еластичне симетрије у дрву смреке, јасена, топола и храста. 